Veterinary Serum and Vaccine Research Institute, Abbasia, Cairo, Egypt.

\title{
DETECTION OF TRYPANOSOMA EVANSI IN CAMELS USING SYBER GREEN1 REAL TIME PCR ASSAY
}

(With One Picture and 2 Figures)

\author{
By \\ M.R. YOUSEF; R.M. AL-KHATIB; K.S. MAZLOUM*; \\ A. AL-SUKAYRAN* and H.M. AL NAKHLI* \\ * National Agriculture and Animal Resources Research Center, \\ Ministry of Agriculture, Riyadh. KSA
}

(Received at 15/9/2010)

\section{الكشف عن طفيل التريبانوسوما إيفانساى فى الجمال باستخدام تفاعل البلمرة المتسلسل ذو الزمن الحقيقي في الجياي}

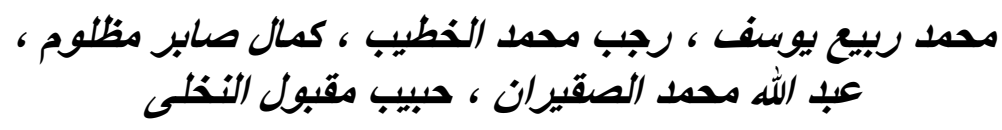

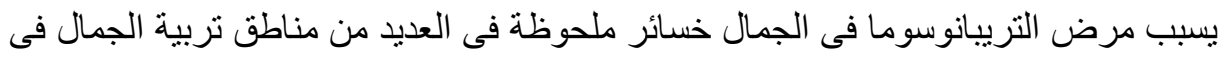

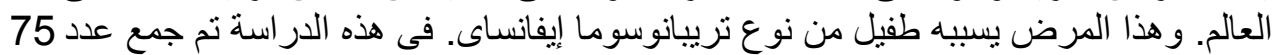

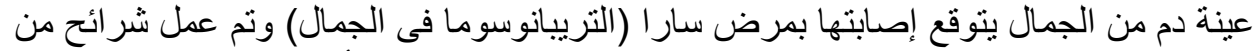

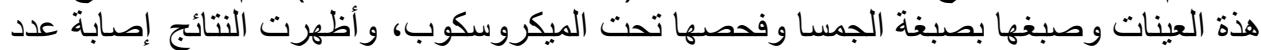

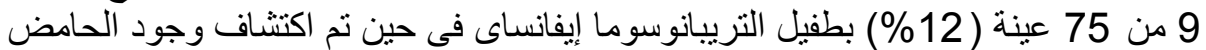

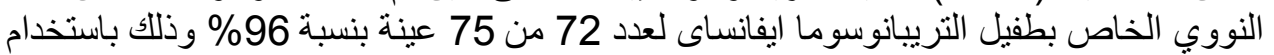

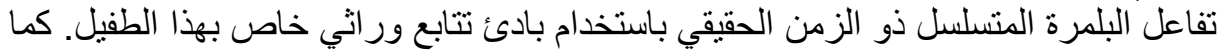

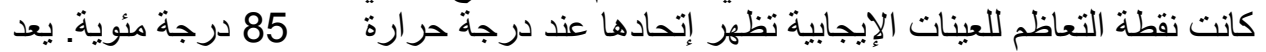

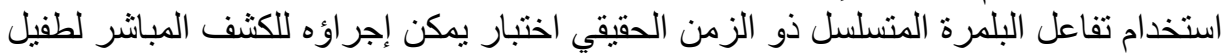

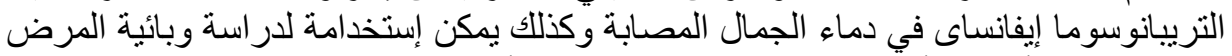

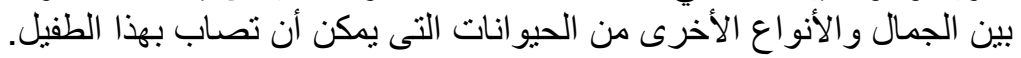

\section{SUMMARY}

Camel Trypanosomasis caused by Trypanosoma evansi is still a serious problem in camel husbandry which causes considerable losses in many camel-rearing regions of the world. In the present study, 75 camels clinically suspected for Surra were examined parasitologicaly by Giemsa stained blood smear and for DNA amplification by real time PCR. Giemsa stained blood smears on microscopical examination detected only 9 out of 
75 camels (12\%) as positive for the presence of T. evansi. While, Out of 75 DNA samples prepared from camel blood, 72 were positive by real time PCR assay (96\%). Primers (TR3, TR4) derived from nuclear repetitive gene of T.evansi and SYBER Green1 fluorescent dye has been used. The melting peak chart of the positive samples showed one single peak at an average $\mathrm{Tm}$ of $85.0^{\circ} \mathrm{C}$. Application of this real time PCR to clinical samples resulted in rapid, direct detection of $T$. evansi in blood of naturally infected camels. The described real time PCR provides a valuable tool to study the epidemiology of T.evansi infection in camels and other susceptible animal population.

Key words: Camels, Real time PCR, SYBER Green 1, Trypanosoma evansi.

\section{INTRODUCTION}

Camel is the principle domestic animals in Saudi Arabia and its meat and milk still constitute a vital source of animal proteins to nomads and city dwellers (Banaja and Ghandour, 1994). Camel Trypanosomasis, Surra, is a disease of camels caused by Trypanosoma evansi. The disease is the most important single cause of economic losses in camel rearing areas, causing morbidity of up to $30.0 \%$ and mortality of around 3.0\% (Ngerenwa et al., 1993, Egbe-Nwiyi and Chaudry, 1994; Pacholek et al., 2001; Njiru et al., 2002). Trypanosomasis is the most important and serious pathogenic protozoal disease of camel caused by Trypanosoma species. This parasite has a wide range of distribution throughout tropical and sub-tropical regions of the world. T. evansi was reported originally from India, where the term 'Surra' is used to describe the disease (Shah et al., 2004).

The causative agent, Trypanosoma evansi, was discovered by Griffith Evans in 1880 in infected camels and equids in the Dara Ismail Khan District of Punjab (Evans, cited by Indrakamhang, 1998). Since then, studies have shown that the parasite can infect all species of domesticated livestock, although the principal host varies geographically (Indrakamhang, 1998; El-Sawalhy and Seed, 1999; Al-Rawashdeh et al., 2000; Diab et al., 1984) recorded the first report $T$. evansi in imported and indigous camels in the Eastern and Southern region of Saudi Arabia.

Camelid trypanosomasis can be acute, but it is usually chronic. It mainly results in wasting, anemia, edema and abortions. Mortality is high in untreated cases (Itard, 1989; Luckins, 1992).

The diagnosis of disease is problematic because the commonly used tests have important limitations. Clinical signs are variable and non specific 
while parasitological examination frequently fails to detect latent infection when parasitaemia is scanty in peripheral blood, especially in chronic form (Chaudhary and Iqbal, 2000). Early detection of T.evansi plays an important role in the epidemiology and animal health (Viseshakul and Panyim, 1990).

Both of the conventional parasitological methods and serological techniques lack sensitivity and specificity. Therefore molecular techniques, especially polymerase chain reaction (PCR) have been developed in order to overcome the problems faced by conventional and serological techniques. In addition, it was reported that PCR is a reliable method for diagnosis and epidemiological studies (Omanwar et al., 1999).

Polymerase chain reaction assay (PCR) amplifying genetically defined regions of genome parasites including trypanosomes are currently of great interest (Wuyts et al., 1994). Molecular tests for T .evansi could potentially improve diagnostic accuracy by using techniques such as PCR to detect T. evansi in blood (Wuyts et al., 1995). Detection of minute amounts of trypanosomal DNA using PCR procedure is a possible mean of identifying animals with active infections, and could have the sensitivity and specificity required. The PCR has used been in surveys to determine the prevalence of T.evansi in camels from different regions in Kenya (Njiru et al., 2004) and in buffaloes in Vietnam (Holland et al., 2004).

However, real time PCR has not been systematically used for detection of T.evansi in camels in Saudi Arabia. In this study, we described a simple, rapid, sensitive and specific assay for detection of $T$. evansi in blood of suspected camels in Saudi Arabia using the real time PCR SYBER Green assay.

\section{MATERIALS and METHODS}

\section{Collection of blood samples:}

Seventy five blood samples were collected from suspected clinical camels through jugular vein. Blood samples were collected in clean sterile vacutainers, containing ethylene diamine tetra acetic acid (EDTA) was preserved at $-20^{\circ} \mathrm{C}$ for extraction of total nucleic acids for use as target DNA for PCR amplification. Blood from animals identified positive by microscopy were used as positive control. Blood from healthy camels (proved negative by wet blood film and mouse inoculation test) were used as negative controls.

\section{Microscopy:}

75 thin blood smears were also prepared at the time of collection of 
blood. They were air dried, fixed in methanol for 2 minutes and allowed to dry, then stained by Giemsa stain $10 \%$ and were examined under oil immersion lens $(100 x)$.

\section{Extraction of DNA from blood samples:}

Automated extraction of total genomic DNA from the whole blood by BioRobot EZ1 workstation (Qiagen $®)$ using EZ1 DNA blood kit (Qiagen $\left.{ }^{\circledR}\right)$ according to the manufacturer's instructions.

\section{Primers:}

T.evansi repetitive DNA primers were designed and synthesized in Biolegio BV®, Belgium to amplify a single band of $257 \mathrm{bp}$ PCR product according to Chansiri et al. (2002):

TR3 ( $5^{\prime}$ GCGCGGATTCTTTGCAGACGA $3^{\prime}$ )

TR4 (5' TGCAGACACTGGAATGTTACT 3')

\section{Real times PCR assay:}

Polymerase chain reaction was carried out in LightCycler 2.0 $\left(\right.$ Roach $\left.^{\circledR}\right)$.The PCR mixture $(20 \mu \mathrm{l})$ contained $15 \mu$ l of reaction mixture containing Fast start DNA Master plus SYBER Green 1(Roach $\left.{ }^{\circledR}\right)$ and 10 pmol/ $\mu 1$ concentration of each primer and $5 \mu \mathrm{l}$ of genomic DNA. The PCR profile was performed as following; pre-heated for 1 cycle at $90{ }^{\circ} \mathrm{C}$ for 10 min and then denatured at $94{ }^{\circ} \mathrm{C}$ for $5 \mathrm{sec}$, annealing at $55^{\circ} \mathrm{C}$ for $10 \mathrm{sec}$ and extension at $72{ }^{\circ} \mathrm{C}$ for $10 \mathrm{sec}$. The PCR amplification was performed for 45 cycles. Fluorescence data were acquired at the end of each cycle in a single step. Once the plateau phase of the PCR had been reached, amplification was stopped and a standard melting curve analysis was performed $\left(95^{\circ} \mathrm{C}\right.$ for 0 second, $65^{\circ} \mathrm{C}$ for 10 seconds, and a $0.1^{\circ} \mathrm{C} /$ second rise to $95^{\circ} \mathrm{C}$ ) with continual fluorescence measuring. PCR data were analyzed using LightCycler2 software version 4.05.

\section{RESULTS}

\section{Microscopic Examination:}

Giemsa stained blood smears on microscopical examination detected only 9 out of 75 camels $(12 \%)$ as positive for the presence of T. evansi (Picture 1). 


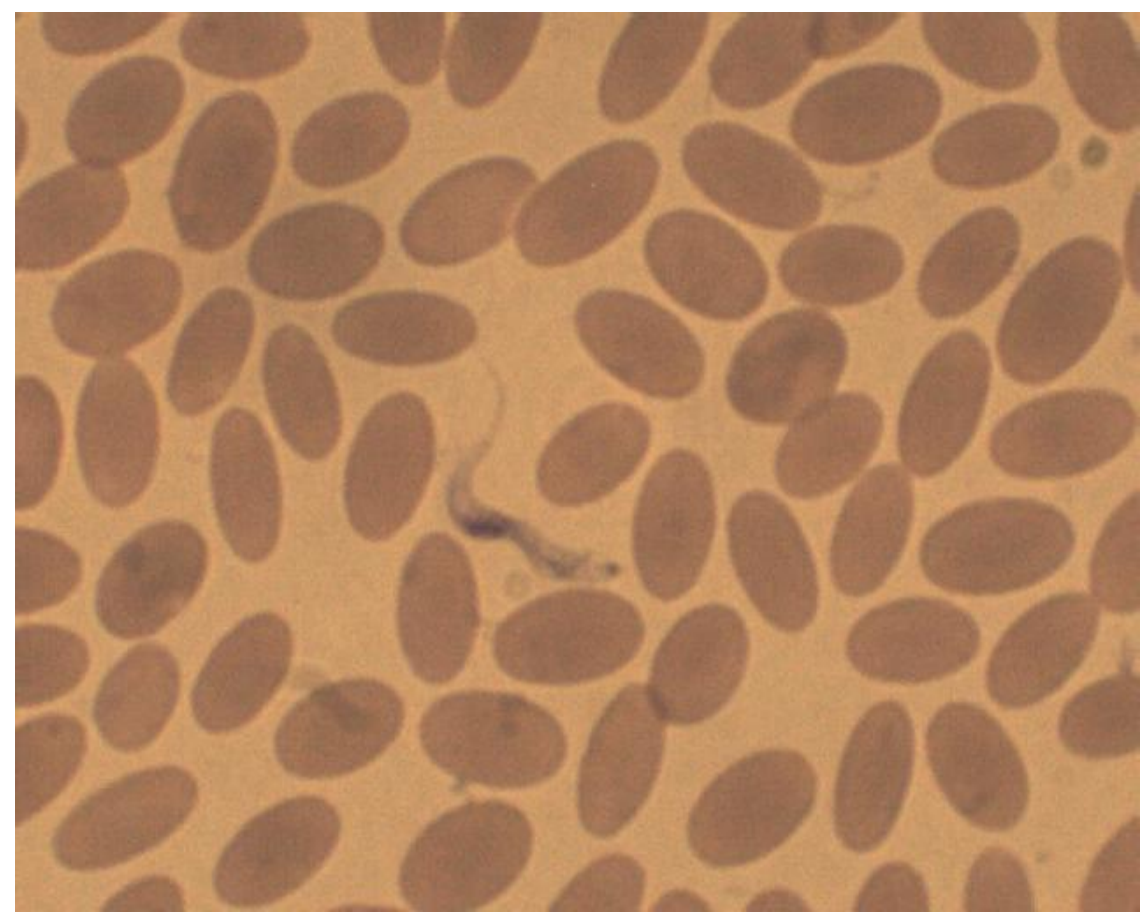

Picture 1: Positive Giemsa stained blood smear, x100.

\section{Real time PCR assay:}

\section{1 - Optimizing of PCR}

The optimization of the real time PCR reaction components and cycling parameters were performed respectively. Different annealing / elongation temperatures and times were evaluated. The optimized concentration of reaction components and cycling parameters were established as described previously (Figure 1).

\section{2 - Melting curve analysis:}

DNA melting curve analysis was performed to identify DNA products from the melting temperature(Tm) of each sample. The melting peak chart of the positive samples showed one single peak at an average $\mathrm{Tm}$ of $85.0^{\circ} \mathrm{C}$. Neither amplification nor primers dimmers formation occurred without T.evansi DNA template (Figure 2).

The result showed the infection in most suspected samples. Out of 75 DNA samples prepared from camel blood, 72 were positive by real time PCR assay therefor the efficiency of detection by this technique was $96 \%$. 


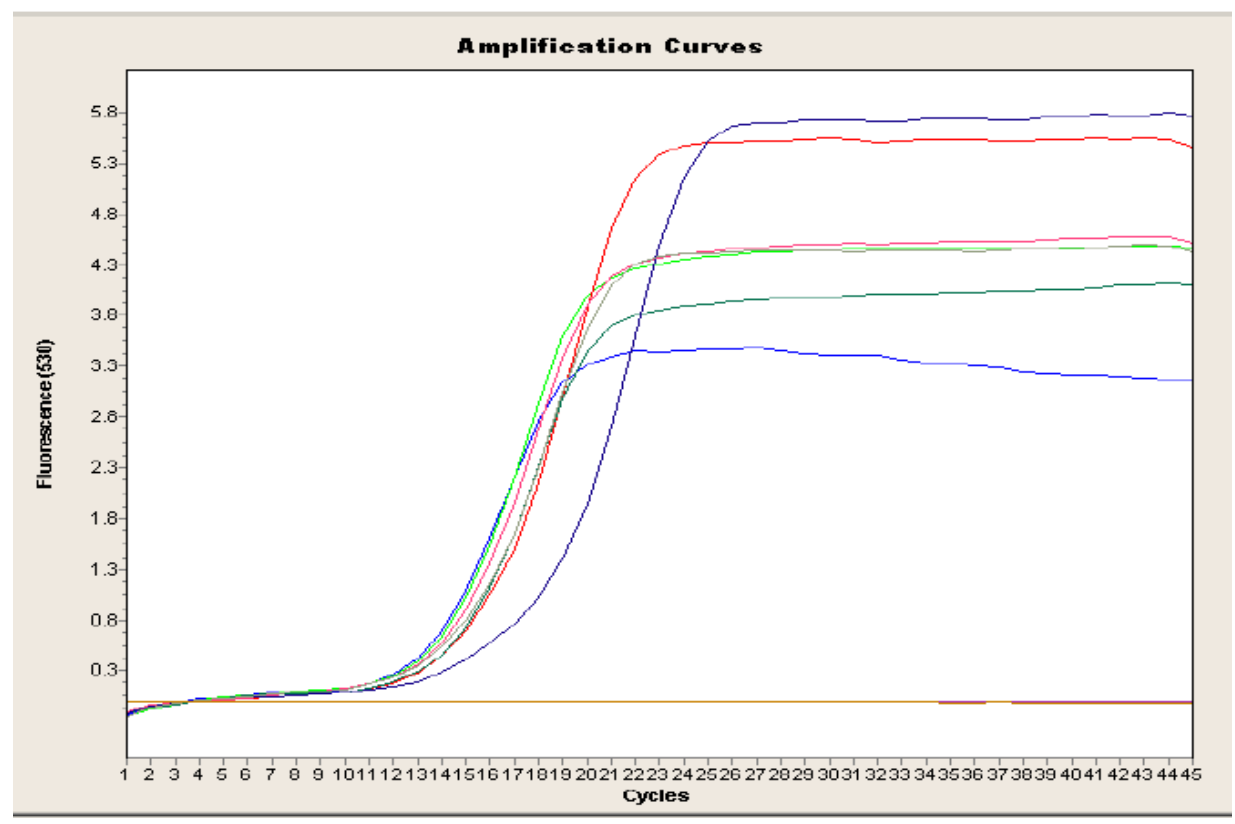

Fig. 1: Amplification curve of real time PCR

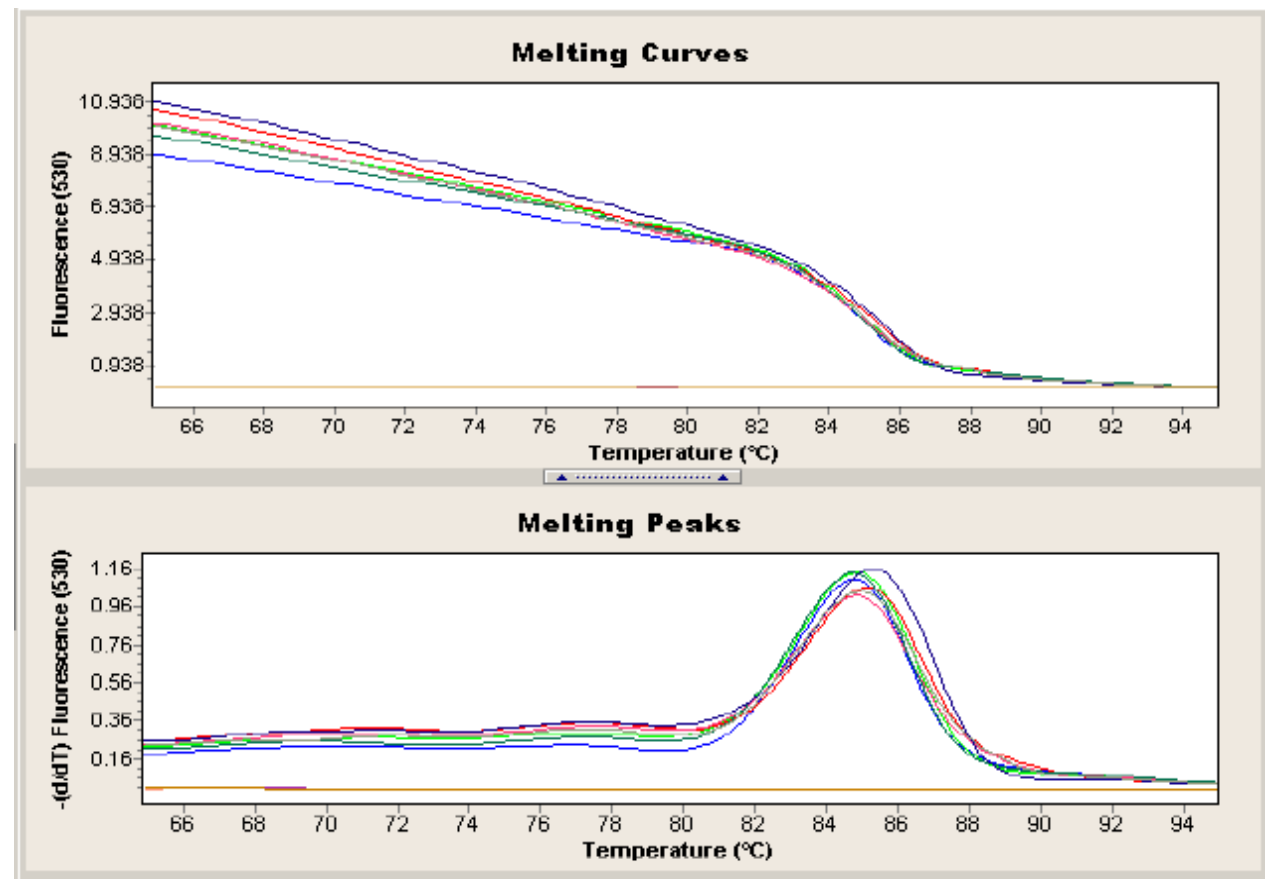

Fig. 2: Melting curve analysis of amplicon obtained from real time PCR. 


\section{DISCUSSION}

Because of the limitations of immunological techniques (Pathak et al., 1997) and the difficulty of demonstrating the parasite in blood smears due to the intermittent nature of parasitaemia (Nantulya, 1990), So there is an urgent need for sensitive and unequivocal detection of acute disease conditions and chronic carrier states.

In the present study only 9 animals were identified positive by microscopy out of 75 samples (12\%) tested. These results agree with Paris et al. (1982) who found the sensitivity of microscopic examination from Giemsa stained thin blood film was $10^{5}$ trypanosomes per $\mathrm{ml}$ of blood. So, blood smear examination proved to be of limited value in diagnosis of subacute or chronic cases.

On the other hand, the diagnostic sensitivity of the present real time PCR assay using primers derived from nuclear repetitive gene of T.evansi and SYBER Green1 fluorescent dye was $96 \%$. This sensitivity is higher than the sensitivity recorded by other assays. El-Metanawy et al. (2009) found that the application of PCR using T.evansi specific primers was the highest method of detection (93.8\%) followed by card agglutination test, mouse inoculation $(55.4 \%)$, buffy coat technique(18.5\%) and wet blood film (13.8\%). Also, Wasana et al. (2000) concluded that the efficiency of detection T.evansi by PCR assay was $93.55 \%$.

The real time PCR assay presents several important advantages over other methods of detection of T.evansi. First, the real time PCR is performed in a closed tube with no post-PCR manipulations, thereby reducing post-PCR processing time. Second, the assay is quick; results can be conformed within 1hour.

In conclusion, the real-time PCR assay is very sensitive and specific assay that can detect $T$ evansi in blood samples of naturally infected camels and can be recommended for inclusion in survey and control programs.

Application of this real time PCR on practical scale to determine the prevalence of T.evansi in naturally infected camels in different regions of Saudi Arabia is in progress.

\section{REFERENCES}

Al-Rawashdeh, O.F.; Sharif, L.A.; Al-Qudah, K.M. and Al-Ani, F.K. (2000): Trypanosoma evansi infection in camels in Jordan. Revue. Elev. Med. Vet. Pays Trop., 20: 233-237. 
Banaja, A.A. and Ghandour, A.M. (1994): A review of parasites of camels in Saudi Arabia. Journal of King Abdul-Aziz University, Science, 6: $75-86$.

Chansiri, K.; Khuchareontaworn, S. and Sarataphan, N. (2002): PCRELISA for diagnosis of T.evansi in animals and vector. Moleculer and Cellular Probes 16: 173-177.

Chaudary, Z.I. and Iqbal, J. (2000): Incidence, biochemical and hematological alterations induced by natural trypanosomasis in racing dromedary camels. Acta.Trop., 77: 209-213.

Diab, F.M.; Al Asgah, N.A.; Al Khalifa, M.S. and Hussein, H.S. (1984): Ticks and blood parasites from indigenous domesticated animals in Saudi Arabia. $7^{\text {th }}$ Symposium on biological aspects of Saudi Arabia, Qassim, p79.

Egbe-Nwiyi, T.N. and Chaudry, S.U.R. (1994): Trypanosomosis: Prevalence and pathology of camel of arid zone of north eastern Nigeria. Trop. Vet 20: 30-34.

El-Metanawey, T.M.; Nadia, M. El-Beih; Abdel El-Aziz, M.M.; Hassanane, M.S. and Abd El-Aziz, T.H. (2009): Comparative Studies on Diagnosis of Trypanosoma evansi in Experimentally Infected Goats. Global Veterinaria, 3 (4): 348-353.

El-Sawalhy, A. and Seed, J.R. (1999): Diagnosis of Trypanosomasis in experimental mice and field-infected camels by detection of antibody to Trypanosome tyrosine amino transferase. J. Parasitol., 40: 1245-1249.

Holland, W.; Thanh, N.G.; MY, L.N.; DO, T.T.; Gooddeeris, B.M. and Vercruysse, J. (2004): Prevalence of Trypanosoma evansi in water buffalos in remote areas in Northern Vietnam using PCR and serological methods. Trop. Anim. Health Prod., 36: 45-48.

Indrakamhang, P. (1998): Trypanosoma evansi infection in livestock in Thailand. J. Protozool. Res., 8: 153-161.

Itard, J. (1989): African animal Trypanosomiasis. In:Manual of Tropical Vetrinary Parasitology.C.A.B. Int., Wallingford.

Luckins, A.C. (1992): In:Protozoan diseases of camel.pp.23-27.Proc. $1^{\text {st }}$ Int. camel Conf., U.A.E., Dubai.

Nantulya, V.M. (1990): Trypanosomiasis in domestic animals. Rev. Sci. Tech. Off. Int. Epizoo., 9: 357-367.

Ngerenwa, J.J.; Gathumbi, P.; Mutiga, E.R. and Agumba, G.J. (1993): Pathogenesis of Trypanosoma brucei evansi in small east African goats. Res. Vet Sci., 54: 283-289. 
Njiru, Z.K.; Constantine, C.C.; Ndung'U, J.M.; Robertson, I.; Okaye, S.; Thompson, R.C. and Reid, S.M. (2004): Detection of Trypanosoma evansi in camels using PCR and CATT/T. evansi tests in Kenya. Vet. Parasitol., 124: 187-199.

Njiru, Z.K.; Bett, O.; Ole-Mapeny, I.M.; Githiori, J.B. and Ndung'U, J.M. (2002): Trypanosomasis and helminthosis in camels: comparison of ranch and traditional camel management systems in Kenya. J. Camel Practice Research, 55: 67-71.

Omanwar, S.; Rao, S.; Basagoudanavar, S.H.; Singh, R.K. and Butchaiah, G. (1999): Direct and sensitive detection of Trypanosome evansi by PCR. Acta Vet. Hung., 47: 351-359.

Pacholek, X.; Gamatic, D.; Franek, S.G. and Tibayrene, R. (2001): Prevalence of Trypanosoma evansi Trypanosomasis in young camels in west Niger. Revue. Elev. Med. Vet. Pays. Trop., 44: 177-182.

Paris, J.; Murray, M. and Mcodimba, F. (1982): A comparative evaluation of the parasitological techniques currently available for the diagnosis of African Trypanosomiasis in cattle.Acta.Trop., 39: 307-316.

Pathak, M.L.; Yadavendra, S.; Meirvenne, N.V. and Kapoor, M. (1997): Evaluation of various diagnostic techniques for trypanosoma evansi infections in naturally infected animals. Ve.t Parasitol., 69: 49-54.

Shah, S.R.; Phulan, M.S.; Memon, M.A.; Rind, R. and Bhatti, W.M. (2004): Trypanosomes infection in camels. Pakistan Vet. J., 24(4): 1-2.

Viseshakul, N. and Panyim, S. (1990): Specific DNA probe for sensitive detection of T.evansi. The Southeast Asian Journal of Tropical Medicine and Public Health, 21: 21-27.

Wasana, S.; Khuchareontaworn, S.; Sarataphan, N.; Viseshakul, N. and Chansiri, K. (2000): Application of PCR-based assay for diagnosis of T.evansi in different animals and vector. J. Trop. Med. Parasitol., 23, (1): 1-6.

Wuyts, N.; Chokesajjawattee, N. and Panyim, S. (1994): A simplified and highly sensitive detection of Trypanosoma evansi by DNA amplification. Southeast Asian J. Trop. Med. Public Health, 25: 226-271.

Wuyts, N.; Chokesajjawattee, N.; Sarataphan, N. and Panyyim, S. (1995): PCR amplification of crude blood on microscopic slides in the diagnosis of Trypanosoma evansi infection in dairy cattle. Annual society of Belgium Medical Tropics, 75: 229-237. 